\title{
IMPLEMENTATION OF DISCOVERY LEARNING MODEL IN SCIENCES LEARNING AT MIN 1 BANTUL AND SDIT BAIK BANTUL
}

\author{
Emha Dzia'ul Haq \& Andi Prastowo \\ emha.ulhaq@gmail.com \\ Program Magister Pendidikan Guru Madrasah Ibtidaiyah \\ Fakultas Ilmu Tarbiyah dan Keguruan \\ UIN Sunan Kalijaga Yogyakarta
}

\begin{abstract}
Many findings of learning are still less varied, the learning process has a tendency on certain methods (conventional), and do not pay attention to the level of students' understanding of the information submitted. Learners are less active in the learning process, students listen and write more. Therefore, the scientific approach brings out learning centered on the learner. And it can be collaborated with Discovery Learning model. This study aims to find out how the implementation of Discovery Learning model in science learning, as well as supporting factors and inhibiting the process of science learning with the Discovery Learning model. The results of this study indicate that: the implementation of Discovery Learning model in science learning in class V MIN 1 Bantul and SDIT BAIK Bantul shows that overall teachers have implemented the learning steps of Discovery Learning model (a) stimulation, teachers stimulate learners by giving a (b) problem statement, the teacher gives the picture and the learner identifies the problem contained in the picture, (c) the data collection, the learners are given experience looking for alternative troubleshooting, (d) data processing, training the learners to try and explore the ability. And last (e) verification and generalitation, learners discuss and communicate the results of the discussion in front of the class. While the supporting and inhibiting factors; Supporting factors (1) teachers' patience, (2) interesting learning packaging, (3) available learning media that complied, (4) good communication, (5) high learning motivation of learners. While the inhibiting factors, (1) the process of student assessment, (2) attitudes of students who are too active, (3) characteristics of different students.
\end{abstract}

Keywords: discovery learning model, science learning

\section{IMPLEMENTASI MODEL DISCOVERY LEARNING DALAM PEMBELAJARAN IPA DI MIN 1 BANTUL DAN SDIT BAIK BANTUL}

\begin{abstract}
Abstrak: Banyak di temukannya pelaksanaan pembelajaran yang masih kurang variatif, proses pembelajaran memiliki kecenderungan pada metode tertentu (konvensional), dan tidak memperhatikan tingkat pemahaman siswa terhadap informasi yang disampaikan. Peserta didik kurang aktif dalam proses belajar, siswa lebih banyak mendengar dan menulis. Maka dari itu, pendekatan saintifik mengeluarkan pembelajaran yang berpusat pada peserta didik. Dan dapat dikolaborasikan dengan model discovery learning. Penelitian ini bertujuan untuk
\end{abstract}




\section{Emha \& Andi, Implementasi Model Discovery Learning...}

mengetahui bagaimana implementasi model discovery learning dalam pembelajaran IPA, serta faktor pendukung dan penghambat proses pembelajaran IPA dengan model discovery learning. Hasil penelitian ini menunjukkan bahwa: implementasi model discovery learning dalam pembelajaran IPA di kelas V MIN 1 Bantul dan SDIT BAIK Bantul, menunjukkan bahwa secara keseluruhan guru sudah melaksanakan langkah-langkah pembelajaran model discovery learning (a) stimulasi, guru menstimulus peserta didik dengan memberikan sebuah gambar, (b) problem statement, guru memberikan gambar lalu peserta didik mengidentifikasi masalah yang terdapat dalam gambar terebut, (c) data collection, peserta didik diberikan pengalaman mencari alternatif pemecahan masalah, (d) data processing, melatih peserta didik mencoba dan mengeksplorasi kemampuannya. Dan yang terakhir (e) verification dan generalitation, peserta didik berdiskusi dan mengkomunikasikan hasil diskusinya di depan kelas. Sedangkan faktor pendukung dan pengahambat; Faktor pendukung (1) ketelatenan guru, (2) pengemasan pembelajaran yang menarik, (3) tersedia media pembelajaran yang memadahi, (4) terjalinnya komunikasi yang baik, (5) motivasi belajar peserta didik yang tinggi. Sedangkan Faktor penghambat, (1) proses penilaian siswa, (2) sikap peserta didik yang terlalu aktif, (3) karakteristik siswa yang berbeda-beda.

Kata kunci: model discovery learning, pembelajaran IPA

\section{PENDAHULUAN}

Sejalan dengan berkembangnya paradigma dunia tentang makna pendidikan, pendidikan dihadapkan dengan berbagai pekerjaan rumah dengan sejumlah tantangan yang semakin berat. Salah satu dari tantangan nyata tersebut adalah pendidikan hendaknya mampu menghasilkan sumberdaya manusia yang memiliki kompetensi yang utuh (Jumali, Surtikanti, \& Sundari, 2008). Berbeda dengan dekade sebelumnya, kompetensi dan pengetahuan yang diharapkan pada sumberdaya manusia saat ini lebih dititik beratkan dalam bidang sains, untuk menciptakan sumberdaya yang memiliki daya saing pada kompetensi berfikir dan komunikasi (Hamid, 2010).

Kompetensi berfikir artinya bahwa sumberdaya manusia yang ada diharapkan mempunyai kemampuan berfikir luas, kritis, kreatif dan inovatif. Kompetensi komunikasi artinya bahwa sumberdaya manusia nantinya dapat memiliki skill komunikasi yang bagus dalam menyampaikan ide-ide dan gagasan kreatifnya (Syah, 2010). Oleh karena itu, pendidikan saat ini merupakan salah satu kunci gerbang yang sangat penting untuk menuntun setiap individu/orang guna menjadi pribadi yang berhasil.

Berdasarkan data survei hasil penelitian Programme for International Student Assesment (PISA) terbaru tahun 2015, peringkat Indonesia dalam penguasaan remaja berusia 15 tahun terhadap keupayaan Sains, Membaca, dan Matematika masih di lapisan bawah. Meskipun Posisi Indonesia pada 2015 terangkat enam peringkat dibandingkan dengan tahun 2012. Namun, hasilnya belum membanggakan. Rata-rata nilai Sains negara OECD adalah 493. Sedangkan Indonesia baru mencapai skor 403. Untuk matematika, rata-rata negara OECD 490, namun skor Indonesia hanya 386. Sementara dalam Membaca skor rata-rata Indonesia baru 397. Padahal, rata-rata OECD adalah 493 (Angel Gurría OECD Secretary-General, 2015). Capaian skor yang telah dirilis dari 


\section{Emha \& Andi, Implementasi Model Discovery Learning...}

hasil penelitian mengenai performa dan prestasi belajar sains di Indonesia masih sangat rendah dibandingkan negara lain. Indonesia menempati peringkat ke-62 dari 70 negara yang bergabung. Peringkat pertama ditempati oleh negara Singapura dengan score nilai Sains 556.

Sedangkan dari sumber yang lain menerangkan, dari hasil studi TIMSS (Trends in International Mathematics and Science Study), menunjukkan peserta didik Indonesia berada pada ranking 45 dari 48 negara dalam hal melakukan prosedur ilmiah (Kepala Puspendik, 2017). Rendahnya nilai hasil survei menunjukkan belum idealnya pembelajaran khususnya sains yang dilakukan di sekolah-sekolah saat ini. Oleh sebab itu, perlu adanya upaya serius dalam meningkatkan nilai sains peserta didik.

Dan untuk mewujudkan itu semua, pemerintah terus berupaya memperbaiki sistem pendidikan yang ada dengan merumuskan aturan-aturan yang terbaru seperti halnya memperbaharui kurikulum yang telah ada untuk memuluskan cita-cita pendidikan bangsa (Abidin, 2014). Kurikulum yang terbaru yaitu kurikulum 2013, kurikulum ini berbasis kompetensi dengan memperkuat proses pembelajaran dan penilaian autentik (authentic assessment) untuk mencapai kompetensi sikap, pengetahuan, dan keterampilan. Kurikulum ini lebih menitik beratkan belajar mengajar dengan pendekatan ilmiah (scientific approach) dan dengan beberapa model pembelajaran. Kurikulum 2013 bertujuan untuk mempersiapkan manusia Indonesia agar memiliki kemampuan hidup sebagai pribadi dan warga negara yang beriman, produktif, kreatif, inovatif, dan afektif serta mampu berkontribusi pada kehidupan bermasyarakat, berbangsa, bernegara, dan peradaban dunia (Permendikbud No 67 Tahun 2013). Kurikulum ini diharapkan dapat diterapkan disemua sekolah yang ada di Indonesia dan diharapkan dapat mendongkrak prestasi nilai-nilai pelajaran salah satunya nilai IPA/Sains.

Dalam kurikulum terbaru ini, penguatan proses pembelajaran dilakukan melalui pendekatan saintifik, pembelajaran yang mendorong peserta didik lebih mampu dalam mengamati, menanya, mencoba/mengumpulkan data, mengasosiasi/menalar, dan mengomunikasikan (Majid \& Rochman, 2015). Sehingga perlu ditingkatkan lagi penalaran akademik dalam bidang sains bagi peserta didik dalam dunia pendidikan saat ini untuk menciptakan sumberdaya manusia yang bisa berdaya saing secara baik. Oleh sebab itu, diperlukan pembelajaran yang dapat membantu untuk mengembangkan berfikir kritis, kreatif dan inovatif. Salah satunya dalam pendekatan saintifik adalah dengan pembelajaran model penemuan (Discovery Learning). Pembelajaran dengan model seperti ini bisa menjadikan pembelajaran khususnya IPA menjadi lebih efektif dan efisien.

Dalam pembelajaran saintifik pada kurikulum 2013, setiap mata pelajaran khususnya IPA, sangat diharapkan sekali dapat merubah pembelajaran yang dulu tradisional (ceramah) ke dalam pembelajaran yang lebih menarik lagi, karena peserta didik yang akan terlibat langsung dan lebih aktif dalam setiap pembelajaran 


\section{Emha \& Andi, Implementasi Model Discovery Learning...}

(Samatowa,2011). Diharapkan minat dan nilai peserta didik lebih meningkat lagi dalam pembelajaran khususnya pembelajaran sains. Pembelajaran sains yang dulunya disampaikan dengan ceramah dimana peserta didik hanya bisa mengawang-awang atau mengira-ira, sekarang lewat pendekatan saintifik di arahkan kepada pembelajaran langsung terhadap apa yang dipelajari.

Guru dituntut harus memberikan kemudahan untuk proses saintifik ini, dengan mengembangkan suasana belajar yang memberikan kesempatan peserta didik untuk menemukan, menerapkan ide-ide mereka sendiri, menjadi sadar menggunakan strategi mereka sendiri untuk belajar. Guru mengembangkan kesempatan belajar kepada peserta didik untuk meniti anak tangga yang membawa mereka ke pemahaman yang lebih tinggi, yang semula dilakukan dengan bantuan guru tetapi semakin lama semakin mandiri. Oleh karena itu, bagi peserta didik, pembelajaran harus bergeser dari "diberi tahu" menjadi "aktif mencari tahu" (Prastowo, 2014). Dengan model Discovery Learning seperti ini diharapkan memperbaiki nilai IPA/Sains itu sendiri.

Selain itu, pembelajaran Sains merupakan pembelajaran yang dapat membuat peserta didik membangun sendiri kemampuannya dengan cara mengeksplorasi seluruh pikiran dalam mempelajari dan menemukan sendiri konsep belajarnya (Sa'ud, 2011). Sugiharto, menyatakan bahwa produk yang dihasilkan oleh peserta didik ketika melaksanakan pembelajaran sains, yaitu meningkatkan penguasaan pada cara berpikir peserta didik yang berupa fakta, konsep, prinsip, hukum dan teori mengenai alam dan sifatnya yang dihasilkan dari penemuan (discovery) ketika menjalani pembelajaran sains (Sugiharto, 2011).

Pembelajaran pendekatan saintifik model discovery sangat penting untuk diterapkan, karena akan melahirkan anak yang berjiwa kritis, disiplin dan pemberani yang sudah ditanamkan melalui jenjang pendidikan sesuai komponen pembelajaran saintifik yang telah diterapkan di Sekolah Dasar (Suprihatiningrum, 2016). Proses pembelajaran sepenuhnya diarahkan pada pengembangan ketiga ranah yaitu pengembangan ranah sikap, pengetahuan, dan keterampilan tersebut secara utuh/ holistik, artinya pengembangan ranah yang satu tidak bisa dipisahkan dengan ranah lainnya. Dengan demikian, proses pembelajaran secara utuh melahirkan kualitas pribadi yang mencerminkan keutuhan penguasaan sikap/afektif, pengetahuan/kognitif, dan keterampilan yang terintegrasi/psikomotor. Pembelajaran sains yang ideal, yaitu ketika peserta didik mampu belajar dengan mengeluarkan seluruh kemampuan dalam penguasaan pengetahuan yang berupa fakta-fakta, menemukan konsep belajar secara mandiri, dan melakukan kegiatan penemuan seperti seorang ilmuan (Toharudin, 2011). Proses pembelajaran sains diarahkan pada proses penemuan, yaitu peserta didik dapat mencari sendiri pengetahuannya, sehingga peserta didik lebih aktif dalam kegiatan pembelajaran (Howe \& Jones, 1993).

Oleh sebab itu, untuk meningkatkan penguasaan konsep dasar dan menghindari mis konsep oleh peserta didik, pada setiap materi-materi pembelajaran IPA yang ada 


\section{Emha \& Andi, Implementasi Model Discovery Learning...}

dapat dipelajari melalui peningkatan pembelajaran bersifat penemuan (discovery), dari konsep dasar pembelajaran sains sendiri, mengarahkan peserta didik untuk dapat terlibat secara langsung dalam pembelajaran (Abidin, 2014). Penguasaan peserta didik hanya sebatas setengah-setengah dalam memahami proses sains karena kurangnya pemahaman konsep dasar sains itu sendiri (Howe \& Jones, 1993). Dengan kata lain pembelajaran IPA yang sudah menggunakan pembelajaran yang benar untuk mengurangi kesalahan perlu dilakukannya penelitian.

Discovery Learning merupakan suatu rangkaian kegiatan pembelajaran yang melibatkan secara maksimal seluruh kemampuan para peserta didik untuk mencapai dan menyelidiki secara sistematis, kritis, dan logis sehingga mereka dapat menemukan sendiri pengetahuan, sikap dan keterampilan sehingga terwujud adanya perubahan perilaku (Hanifah \& Suhana, 2009). Wilcolx mengatakan bahwa dalam pemebelajaran penemuan, peserta didik didorong untuk belajar aktif melalui keterlibatan aktif mereka sendiri dengan konsep-konsep, prinsip-prinsip dan guru mendorong peserta didik untuk memiliki pengalaman dan melakukan percobaan yang memungkinkan mereka menemukan prinsip-prinsip untuk diri mereka sendiri (Hanifah \& Suhana, 2009).

Menurut Syah (2004) dalam mengaplikasikan model discovery di proses pembelajaran, ada beberapa tahapan pembelajaran yang harus dilaksanakan. Tahapan atau langkah-langkah tersebut secara umum dapat diperinci sebagai berikut:

a. Stimulasi (memberikan rangsangan)

Dalam kegiatan awal ini mempunyai tujuan dengan cara peserta didik dihadapkan kepada sesuatu yang menimbulkan kebingungan dan dirangsang untuk melakukan kegiatan penyelidikan guna menjawab kebingungan tersebut. Kebingungan dalam diri peserta didik ini sejalan dengan adanya informasi yang belum tuntas yang disajikan oleh guru.

b. Problem statement (identifikasi masalah)

peserta didik diarahkan untuk mengidentifikasi sebanyak mungkin masalah yang relevan dengan bahan pelajaran, kemudian salah satunya dipilih dan dirumuskan dalam bentuk hipotesis.

c. Data colection (Pengumpulan data)

merumuskan hipotesis yaitu peserta didik ditugaskan untuk melakukan kegiatan eksplorasi, pencarian, dan penelusuran dalam rangka mengumpulkan informasi sebanyak-banyaknya yang relevan untuk membuktikan benar hipotesis yang telah diajukannya. Kegiatan ini dapat dilakukan melalui aktivitas wawancara, kunjungan lapangan, dan kunjungan pustaka.

d. Data processing (Pengolahan data)

Melakukan kegiatan penemuan yaitu peserta didik mengolah data informasi yang telah diperolehnya baik melalui wawancara, observasi, dan sebagainya, lalu ditafsirkan. 


\section{Emha \& Andi, Implementasi Model Discovery Learning...}

\section{e. Verification (Pembuktian)}

Mempresentasikan hasil kegiatan yaitu peserta didik melakukan pemeriksaan secara cermat untuk membuktikan benar tidaknya hipotesis yang ditetapkan tadi dengan temuan alternatif, dihubungkan dengan hasil pengolahan data.

\section{f. Generalization (Menarik kesimpulan)}

Mengevaluasi kegiatan penemuan yaitu peserta didik menarik sebuah kesimpulan yang dapat dijadikan prinsip umum berlaku untuk semua kejadian atau masalah yang sama, dengan memperhatikan hasil verifikasi.

Seperti halnya apa yang sudah dilakukan oleh sekolah MIN 1 Bantul pembelajaran sains sudah menjadikan peserta didik lebih aktif, karena guru selalu mencoba untuk memberi kesempatan kepada peserta didik untuk berfikir kritis dan mengkomunikasikannya dengan baik setiap kejadian/ pembahasan dalam setiap pembelajaran IPA. Jadi pembelajaran sains yang dulunya hanya sebatas cerita-cerita tentang bentuk, gambar dan halusinasi sehingga dapat menyebabkan mis konsep tentang materi yang diajarkan, sekarang mulai berubah menjadi pembelajaran sains yang menyenangkan, kreatif dan melibatkan peserta didik penuh dalam setiap identifikasi masalah di setiap materi pembelajaran itu sendiri. Inilah yang menjadi pertimbangan penulis untuk melakukan penelitian lebih lanjut tentang pembelajaran sains di sekolah dasar (Hasil wawancara dengan guru kelas V MIN Bantul, 20 Januari 2018).

Menurut Bapak Ahmad Farid, guru di MIN 1 Bantul Proses pembelajaran sains melalui pembelajaran dengan pendekatan saintifik model Discovery Learning perlu ditingkatkan, karena dapat digunakan sebagai landasan awal guna mempersiapkan generasi muda yang mampu mengoptimalkan seluruh kemampuan yang ada dalam dirinya dengan kegiatan pembelajaran dan ilmu yang didapatkan akan diterima oleh peserta didik secara optimal. Keterampilan proses sains akan mengembangkan sikap, wawasan, serta jiwa sosial peserta didik, sehingga dapat menempatkan proses pembelajaran pada posisi yang sama pentingnya dengan hasil belajar yang diperoleh peserta didik (Hasil wawancara dengan guru kelas V MIN Bantul, 20 Januari 2017). Dengan adanya pembelajaran seperti ini dengan cara peserta didik lebih aktif dalam setiap KBM untuk menghindari mis konsep disetiap pembelajaran IPA karena disampaikan secara utuh oleh guru dan peserta didik sebagai pelaku langsung, maka diharapkan pembelajaran seperti ini bisa menjadikan belajar lebih menarik dan tidak monoton, sehingga nilai untuk Sains sendiri ada peningkatan, ketika itu disampaikan pembelajaran yang benar.

Sedangkan menurut Ibu Karwati, S. Pd bahwa peserta didik yang sanggup mengoptimalkan keterampilan proses sainsnya, diharapkan akan dapat menerapkan ilmu yang didapatkan dalam kehidupan sehari-hari dan menjadi bekal pengetahuan di masa yang akan datang (Hasil wawancara dengan guru kelas SDIT BAIK Bantul, 14 Agustus 2017). Oleh sebab itu penulis tertarik dengan kajian ini untuk diangkat lebih dalam ke dalam sebuah penelitian karya ilmiah untuk dijadikan salah satu acuan dalam 


\section{Emha \& Andi, Implementasi Model Discovery Learning...}

pembelajaran Sains/IPA dalam proses pembelajaran Sains kedepannya, sehingga dapat menorehkan generasi yang dapat bersaing dibidang IPTEK.

Dengan demikian, berdasarkan kegelisahan akademik penulis serta di dukung oleh data, wawancara (pra penelitian) dan observasi, maka penulis mencoba untuk melakukan penelitian dengan judul: "Implementasi Model Discovery Learning Dalam Pembelajaran IPA Di MIN 1 Bantul Dan SDIT Baik Bantul”.

Berdasarkan latar belakang masalah, dapat dituliskan rumusan masalah sebagai berikut: 1) Bagaimana proses penerapan Model Discovery Learning dalam pembelajaran IPA di MIN 1 Bantul dan SDIT BAIK Krapyak Bantul, 4) Apa faktor penghambat dan pendukung dalam pembelajaran IPA dengan Model Discovery Learning yang diterapkan di MIN 1 Bantul dan SDIT BAIK Krapyak Bantul.

\section{METODE PENELITIAN}

\section{Jenis Penelitian}

Metode penelitian ini merupakan metode penelitian lapangan (field research). Dikarenakan penelitian ini merupakan penelitian lapangan, maka pengumpulan datanya merupakan telaah atau kajian terhadap hasil observasi, wawancara, dan dokumen yang berupa data sekunder yang kemudian dianalisis dengan teori yang ada, jenis penelitian ini yaitu penelitian kualitatif. Penelitian kualitatif adalah penelitian yang bermaksud untuk memahami fenomena tentang apa yang dialami oleh subyek penelitian, misalnya perilaku, persepsi, motivasi tindakan, dan lain-lain secara holistik dan dengan cara deskripsi dalam bentuk kata-kata dan bahasa, pada suatu konteks khusus yang alamiah dan dengan memanfaatkan berbagai metode alamiah (Moleong, 2007).

Penelitian kualitatif menggunakan desain penelitian studi kasus dalam arti penelitian difokuskan pada fenomena saja yang dipilih dan ingin dipahami secara mendalam, dengan mengabaikan fenomena-fenomena lainnya. Satu fenomena tersebut bisa berupa seorang pemimpin sekolah atau pemimpin pendidikan, sekelompok peserta didik, suatu program, guru pengajar, suatu proses, satu penerapan kebijakan, atau satu konsep (Moleong, 2007). Penelitian kualitatif ini menghasilkan diskripsi dan analisis tentang kegiatan, proses atau peristiwa-peristiwa penting. Studi-studi kasus yang dilakukan secara terpisah dan dalam kurun waktu yang berbeda, tentang fokus-fokus masalah, kegiatan atau program yang sama dapat menjadi masukan yang sangat berharga bagi penyempurnaan praktik. Hasil sejumlah penelitian kualitatif yang bersifat mendalam dan rinci mempunyai nilai yang lebih tinggi dari penelitian kuantitatif (Sukmadinata, 2010). Oleh sebab itu, penulis mencoba mengkaji penelitian ini dengan metode kualitatif dikarenakan lebih cocok untuk memahami fenomena-fenomena sosial dari sudut dan prespektif partisipan. Partisipan adalah orang-orang yang diajak berwawancara, diobservasi, diminta memberi data, pendapat, pemikiran, persepsinya. Selain itu peneliti tertarik untuk mengungkap data khusus, detil, untuk menemukan kategori, dimensi, hubungan penting dan asli, dengan pertanyaan terbuka untuk 


\section{Emha \& Andi, Implementasi Model Discovery Learning...}

membuat subjektif murni dan tidak dibuat-buat. Sehingga dapat menghasilkan hasil yang maksimal.

\section{Subyek Penelitian}

Subyek penelitian adalah sumber utama dalam penelitian yang memiliki data mengenai variabel-variabel yang diteliti (Azwar, 1999). Dalam penelitian kualitatif, teknik sampling yang sering digunakan adalah purposive sampling dan snowball sampling. Tetapi dalam penelitian ini penulis menggunakan teknik pengambilan sampel (purposive sampling). Seperti telah dikemukakan bahwa, purposive sampling adalah teknik pengambilan sampel sumber-sumber data dengan pertimbangan tertentu, memfokuskan pada informan-informan yang kaya dengan kasus untuk studi yang bersifat mendalam (Sugiyono, 2010). Oleh karena itu, penelitian ini akan menggunakan teknik pengambilan sampel (purposive sampling).

Yang menjadi subyek dalam penelitian ini adalah, guru kelas 5 di 2 sekolah yaitu Bapak Ahmad Farid guru kelas 5 MIN 1 Bantul dan Ibu Reni guru kelas 5 SDIT BAIK Bantul, dan peserta didik secara acak yang diperoleh dari nilai IPA dari yang tinggi, sedang dan rendah di MIN 1 Bantul dan SDIT BAIK Yogyakarta.

\section{Metode Pengumpulan Data}

Dalam penelitian ini, pengumpulan data penelitian kualitatif bersifat interaktif, berlangsung dalam lingkaran yang saling tumpang tindih. Langkah-langkahnya biasa disebut strategi pengumpulan data dan analisis data, teknik yang digunakan fleksibel, tergantung pada strategi terdahulu yang digunakan dan data yang telah diperoleh (Sukmadinata, 2010). Dalam penelitian ini, penulis menggunakan beberapa metode untuk mengumpulkan data. Metode-metode yang digunakan dalam penelitian ini adalah:

\section{Interview/ Wawancara}

Salah satu teknik yang digunakan dalam penelitian kualitatif adalah wawancara mendalam. Wawancara mendalam (in-depth interview) adalah proses memperoleh keterangan untuk tujuan penelitian dengan cara tanya jawab sambil bertatap muka antara pewawancara dengan informan atau orang yang diwawancarai, dengan atau tanpa menggunakan pedoman (guide) wawancara, dimana pewawancara dan informan terlibat dalam kehidupan socsial yang relatif lama (Sutopo, 2006). Dalam penelitian ini penulis melakukan wawancara kepada subyek-subyek yang telah ditetapkan untuk mencari data-data yang dibutuhkan. Penulis menggunakan wawancara atau interview bebas terpimpin maksudnya adalah interview ini dilaksanakan dengan menggunakan kerangka pertanyaan yang sudah disiapkan penulis untuk diajukan kepada responden, akan tetapi cara penyampaian pertanyaan tidak terlalu formal harmonis dan tidak kaku sekalipun pewawancara telah terikat oleh pedoman wawancara (Sugiyono, 2010). Data yang diperoleh dari wawancara mendalam berupa pengalaman, pendapat, perasaan, dan pengetahuan ke informan.

Metode ini dilakukan untuk memperoleh informasi mendalam mengenai proses pembelajaran IPA yang dilaksanakan oleh guru kelas dan peserta didik kelas 5 secara 


\section{Emha \& Andi, Implementasi Model Discovery Learning...}

acak yang ada di MIN 1 Bantul dan di SDIT BAIK Krapyak Bantul. Dalam hal ini peneliti akan mewawancarai pihak-pihak terkait yang dapat memberikan informasi, yakni guru kelas 5 dan peserta didik.

Selain itu wawancara juga dilakukan untuk menjaring pendapat, aspirasi dan problematika pembelajaran IPA yang dialami oleh para guru kelas yang mengajar IPA di MIN 1 Bantul dan di SDIT BAIK Krapyak Bantul.

\section{Observasi}

Observasi yaitu teknik pengumpulan data yang dilakukan dengan cara penyelidik dan pengamatan secara langsung (tanpa alat) terhadap gejala-gejala subjek yang diteliti atau diselidiki (Mardalis, 2008). Observasi merupakan kegiatan pengamatan yang dilakukan oleh peneliti, dimana peneliti berperan aktif dalam lokasi studi sehingga benar-benar terlihat dalam kegiatan yang ditelitinya. Dalam observasi ini, peneliti terlibat dengan kegiatan sehari-hari orang yang sedang diamati atau yang digunakan sebagai sumber data penelitian. Observasi dipakai untuk memahami persoalan-persoalan yang ada di sekitar pelaku dan nara sumber (Harsono, 2008).

Teknik observasi ini dilakukan untuk mendapat data tentang langkah-langkah yang dilakukan guru dalam pembelajaran IPA. Observasi dilakukan dengan terjun langsung ke lapangan secara aktif untuk memperoleh gambaran dan keterangan riil mengenai sikap dan perilaku informan. Keterangan dan informasi yang diperoleh kemudian dianalisis, ditafsirkan, dan disimpulkan.

Dalam tahap ini, penulis tidak ambil bagian dalam kegiatan belajar mengajar, tetapi penulis hanya mengamati proses belajar menagajar. Pengamatan dilakukan di sekolahan baik dalam ruangan maupun luar ruangan, meliputi proses pembelajaran IPA di kelas atau di luar kelas, letak geografis sekolah dan keadaan lingkungan sekolah, dan sarana prasarana yang digunakan dalam pembelajaran. Metode ini digunakan untuk mengetahui proses belajar mengajar IPA di MIN 1 Bantul dan SDIT BAIK Krapyak Bantul.

\section{Dokumentasi}

Dokumentasi merupakan catatan peristiwa yang sudah berlalu. Dokumen bisa berbentuk tulisan, gambar, atau karya-karya monumental dari seseorang. Dokumen merupakan catatan peristiwa yang sidah berlalu. Dokumen bisa berbentuk tulisan, gambar, atau karya-karya monumental dari seseorang (Sugiyono, 2010). Metode dokumentasi ini digunakan untuk memperoleh data yang diperoleh dari dokumentasi berupa kutipan, segala macam naskah, catatan program, korespondensi, laporan dan publikasi resmi sekolah. Metode dokumentasi merupakan alat pengumpulan data berupa dokumen-dokumen tertulis seperti Laporan Rencana Pembelajaran, Kurikulum, peraturan-peraturan, notulen rapat dan profil sekolah yang ada di MIN 1 Bantul dan SDIT BAIK Krapyak Bantul. 


\section{Emha \& Andi, Implementasi Model Discovery Learning...}

\section{Teknik Analisis Data}

Menurut Bogdan dan Tylor, analisis data adalah proses mengorganisasikan dan mengurutkan data kedalam pola, kategori dan satuan uraian dasar sehingga dapat ditemukan tema dan dapat dirumuskan hipotesis kerja seperti yang disarankan oleh data (Moleong, 2007).

\section{Reduksi Data}

Reduksi data merupakan kegiatan merangkum catatan-catatan lapangan dengan memilah hal-hal yang pokok yang berhubungan dengan permasalahan penelitian, rangkuman catatan-catatan lapangan itu kemudian disusun secara sistematis agar memberikan gambaran yang lebih tajam serta mempermudah pelacakan kembali apabila sewaktu-waktu data diperlukan kembali (Ghoni \& Almansur).

\section{Display Data}

Display data berguna untuk melihat gambaran keseluruhan hasil penelitian, baik yang berbentuk matrik atau pengkodean, dari hasil reduksi data dan display data itulah selanjutnya peneliti dapat menarik kesimpulan data memverifikasikan sehingga menjadi kebermaknaan data.

\section{Kesimpulan dan Verifikasi}

Untuk menetapkan kesimpulan yang lebih beralasan dan tidak lagi berbentuk kesimpulan yang coba-coba, maka verifikasi dilakukan sepanjang penelitian berlangsung sejalan dengan member chek, trianggulasi dan audit trail, sehingga menjamin signifikansi hasil penelitian. Dalam pengambilan kesimpulan perlu diverifikasi dengan melakukan aktivitas ulangan untuk tujuan agar lebih sempurna, dengan penelusuran data kembali, dengan mengembangkan ketelitian misalnya mengembangkan konsensus antar subyek. Pada prinsipnya harus dilakukan pengujian validitas data agar simpulan penelitian menjadi bisa dipercaya.

Analisis data ini dilakukan dengan model interaktif. Proses analisis interaktif dimulai pada waktu pengumpulan data peneliti selalu membuat reduksi data dan kajian data. Artinya data yang berupa catatan lapangan yang terdiri dari bagian deskripsi dan refleksinya adalah data yang dikumpulkan dan dari situ peneliti membuat ringkasan tentang pengertian yang ada yang disebut reduksi data. Setelah selesai, peneliti mulai melakukan usaha menarik kesimpulan dengan verifikasi yang berdasarkan pada reduksi data dan sajian data. Bila data yang ada dalam reduksi data dan sajian data kurang lengkap, maka wajib melakukan pengumpulan data kembali yang mendukung. Dengan analisis interaktif akan diperoleh gambaran yang jelas mengenai gambaran rencana anggaran dan pembelanjaan biaya pendidikan.

\section{Uji Keabsahan Data}

Setelah melakukan analisis data yaitu selanjutnya diperlukan uji kredibilitas data dengan menggunakan cara Triangulasi. Yang mana Triangulasi dalam pengujian kredibilitas ini diartikan sebagai pengecekan data dari berbagai sumber dengan berbagai 


\section{Emha \& Andi, Implementasi Model Discovery Learning...}

cara dan berbagai waktu. Dengan demikian terdapat triangulasi sumber, triangulasi teknik pengumpulan data, dan waktu. Triangulasi sumber untuk menguji kredibilitas data dilakukan dengan cara mengecek data yang telah diperoleh melalui beberapa sumber, triangulasi teknik digunakan untuk menguji kredibilitas data dilakukan dengan cara mengecekan data kepada sumber yang sama dengan teknik yang berbeda, dan triangulasi waktu digunakan untuk kredibilitas data (Moleong, 2007).

\section{HASIL DAN PEMBAHASAN}

Dari paparan hasil penelitian, bisa dilihat implementasi model Discovery Learning dalam pembelajaran IPA di kedua sekolah. Bisa dilihat dan dipahami, masingmasing memiliki cara penyampaian yang berbeda dan ada juga yang sama. Dalam tahap awal yaitu pemberian rangsangan (stimulasi), pembelajaran kelas V di MIN 1 Bantul, guru memberikan sebuah gambar, vidio atau buku dan peserta didik mengamati, melihat dan membaca dengan seksama agar timbul sebuah permasalahan/pertanyaan menantang yang tidak hanya memiliki satu jawaban sehingga siswa dihadapkan pada sesuatu/situasi yang menyebabkan kebingungannya kemudian muncul keinginan untuk memikirkan alternatif jawaban sesuai dengan pengetahuannya dan belajar membuat jawaban sementara (hipotesis) berdasarkan permasalahan/pertanyaan yang diajukan. Sedangkan di SDIT BAIK Bantul, guru memberikan rangsangan kepada peserta didik berupa sebuah pertanyaan-pertanyaan kepada peserta didik, kemudian peserta didik menjawab dan sebaliknya. Di dalam tahap ini kedua kelas tersebut sama-sama memberikan rangsangan terlebih dahulu sebelum memulai pembelajarannya.

Pada tahap kedua identifikasi masalah (problem statement) pembelajaran IPA di kedua kelas melakukan identifikasi masalah dengan cara melakukan diskusi kelompok serta mencari referensi sebanyak-banyaknya lewat buku, LKS, dan Internet. Ini berarti dalam tahap ini guru sama-sama menggunakan metode pembagian kelompok dalam proses pembelajarannya agar peserta didik lebih banyak lagi dalam mengumpulkan sebuah masalah sebelum dilakukan tahap selanjutnya. Dalam model Discovery Learning guru menghidupkan suasana kelas dengan membentuk kelompok diskusi pada saat pembelajaran. Hal ini diyakini tidak hanya mampu meningkatkan kemampuan kognitif peserta didik saja, namun juga jiwa sosial peserta didik dimana dalam satu kelompok peserta didik yang memiliki kemampuan lebih akan memberikan penjelasan kepada peserta didik yang kemampuannya kurang. Kegiatan belajar kelompok memberikan informasi bahwa peserta didik tidak hanya aktif dalam melakukan kegiatan bertanya saja, namun juga aktif dalam melakukan interaksi dengan teman-teman dalam satu kelas melalui kegiatan diskusi.

Pada tahap ketiga pengumpulan data (data colection) di dalam pembelajaran IPA yang dilakukan di kedua kelas tersebut melakukan observasi langsung baik itu praktek didalam maupun diluar kelas tergantung tema yang sedang dikaji. Kedua kelas sama-sama menjalani tahap ini dengan baik dan berhasil. Dalam pembelajaran di MIN 1 


\section{Emha \& Andi, Implementasi Model Discovery Learning...}

peserta didik melakukan kegiatan membaca sebanyak-banyaknya untuk mendapatkan jawaban dalam soal yang telah diberikan oleh guru. sedangkan pembeljaran di SDIT BAIK peserta didik selain membaca juga melakukan percobaan langsung diluar kelas untuk memperoleh informasi-informasi yang dibutuhkan. Dalam tahap ini penulis memberikan masukan untuk guru lebih mendorong peserta didik agar lebih banyak lagi aktif dalam membaca buku dan mmenggunakan media berupa internet.

Pada tahap keempat pengolahan data (data processing) masing-masing siswa melakukan diskusi dengan kelompok masing-masing, dan akan membentuk sebuah kesimpulan di masing-masing kelompok, yang akan di jelaskan di dalam kelas dengan meningkatkan kemampuan belajarnya dengan menggunakan berbagai sumber belajar yang relevan untuk mencari dan memecahkan permasalahan. Seperti melakukan pengamatan langsung ke gambar, membaca buku panduan dan melakukan diskusi kelompok. Selama kegiatan menga-sosiasi atau diskusi ini tidak dapat dipungkiri bahwa setiap siswa itu berbeda, masih ada beberapa yang mengobrol send-iri. Oleh karena itu penulis menyimpulkan dalam tahap ini keterlibatan guru sangat diperlukan untuk mengawasi jalannya diskusi agar mereka dapat bekerja sama dengan baik.

Pada tahap kelima verifikasi (verification) masing-masing kelas baik di MIN 1 Bantul maupun di SDIT BAIK Bantul guru menjadi fasilitator antar kelompok, pada tahap ini setelah data diolah maka hasilnya dibandingkan dengan jawaban peserta didik diawal, apakah sudah sesuai dengan jawaban diawal atau belum. Selanjutnya pada tahap terakhir kesimpulan (generalizaton) guru bersama peserta didik melakukan evalusai dan kesimpulan tentang pembelajaran yang telah dilakukan, dan guru memberi masukan ke beberapa kelompok yang belum baik dalam melakukan analisis tugas.

Kegiatan akhir atau penutup guru melakukan refleksi bersama dengan peserta didik. Kegiatan refleksi ini merupakan kegiatan berpikir tentang apa yang sudah dipelajari selama proses pembelajaran. Kegiatan refleksi dilakukan untuk menganalisis hasil kegiatan pembelajaran yang sudah dilakukan. Guru memberikan kesempatan peserta didik untuk berpikir dan mengambil kesimpulan.

Penerapan pembelajaran dengan model Discovery Learning pada pembelajaran IPA di MIN 1 Bantul dilakukan dengan persiapan materi dan bahan seperti media yang ada akan digunakan untuk menunjang penyampaian materi nantinya salah satunya dengan gambar dan video serta LCD. Hal tersebut dilakukan sebagai kegiatan awal dalam proses penerapan model Discovery Learning. Selain itu, pembelajaran praktikum diluar kelas yang dilakukan di SDIT BAIK juga membuat suasana yang berbeda. Hal lain yang membuat peserta didik tertarik dan memberikan kesan yang berbeda adalah pada saat guru menerangkan tentang materi getaran, saat observasi dikelas guru tersebut memberikan contoh hasil getaran, bahwa hasil getaran bisa dilihat pada kehidupan sehari-hari, guru meminta salah satu peserta didik untuk melakukan percobaan dengan memukulkan penggaris pada meja, lalu muncullah sebuah getaran. Guru mengimplementasi konsep dengan memberikan materi sedikit demi sedikit dan dari 


\section{Emha \& Andi, Implementasi Model Discovery Learning...}

materi yang mudah ke materi yang kompleks. Selain itu guru memberikan pengalaman yang bermakna dengan meminta peserta didik untuk melakukan kegiatan eksperimen.

Berdasarkan uraian dan keterangan di atas maka dapat diambil kesimpulan bahwa dalam pelaksanaan penerapan model Discovery Learning pada pembelajaran IPA kelas V MIN 1 Bantul dan SDIT BAIK Bantul didapat hasil bahwa dalam pelaksanaan penerapan model Discovery Learning ini telah sesuai dengan sintaks yang telah dirumuskan sebelumnya yaitu pertama, pendahuluan yang merupakan kegiatan awal dalam suatu pertemuan pembelajaran yang ditujukan untuk membangkitkan motivasi dan memfokuskan perhatian peserta didik untuk berpartisipasi aktif dalam proses pembelajaran. Kedua, kegiatan inti yang merupakan proses pembelajaran untuk mencapai KD. Kegiatan pembelajaran dilakukan secara interaktif, inspiratif, menyenangkan, menantang, memotivasi peserta didik untuk berpartisipasi aktif, serta memberikan ruang yang cukup bagi prakarsa, kreativitas, dan kemandirian sesuai dengan bakat, minat, dan perkembangan fisik serta psikologis peserta didik. Ketiga, penutup yang merupakan kegiatan yang dilakukan untuk mengakhiri aktivitas pembelajaran yang dapat dilakukan dalam bentuk rangkuman atau simpulan, penilaian dan refleksi, umpan balik, dan tindak lanjut.

Oleh karena itu, melalui model tersebut siswa melakukan percobaan, bagi anak usia Sekolah Dasar (SD) pembelajaran lebih menarik dengan percobaan, karena dengan percobaan siswa melakukan penemuan sendiri, tidak hanya teori yang diterima siswa namun ada kesinambungan dan pembuktian antara teori dengan fakta. Pemaparan diatas sesuai dengan kelebihan-kelebihan model discovery learning yang diungkapkan oleh Berlyne yaitu model ini kegiatan dan pengalaman dilakukan secara langsung sehingga lebih menarik perhatian anak didik untuk belajar dan memungkinkan pembentukan konsep-konsep abstrak yang mempunyai makna, serta memberi banyak kesempatan bagi siswa untuk terlibat langsung dalam kegiatan belajar (Suprahitingrum, 2016). Penerapan model Discovery Learning disesuaikan dengan teori konstruktivisme Bruner yang mencakup gagasan belajar sebagai proses aktif dimana pembelajaran tersebut mampu membentuk ide-ide baru berdasarkan apa pengetahuan mereka saat ini serta pengetahuan masa lalu mereka.

Pembelajaran dengan menerapkan model Discovery Learning pun secara tidak langsung sudah melaksanakan apa yang sebenarnya harus ada dalam pembelajaran IPA, yaitu memberikan pengalaman langsung, melakukan pengamatan, memahami hasil pengamatan, hingga menerapkan konsep. Dengan demikian alternatif pemecahan masalah yang diambil dengan menerapkan model discovery leraning untuk mengatasi masalah yang ditemukan ternyata dapat menjawab hipotesis yang sudah peneliti buat. Secara keseluruhan dari model pembelajaran Discovery Learning yang dilakukan di kedua kelas sudah melaksanakan semua tahapan proses pembelajaran dengan menggunakan model Discovery Learning dengan baik. Hanya saja terkadang urutannya tidak urut, tetapi secara umum sudah disebut baik. 


\section{Emha \& Andi, Implementasi Model Discovery Learning...}

Selain itu, dalam pembelajarn IPA model ini memiliki beberapa Faktor pendukung dan penghambat. Faktor pendukung: (1) ketelatenan guru; (2) pengemasan pembelajaran yang menarik siswa; (3) sarana dan prasarana yang baik; (4) komunikasi yang efektif; (5) motivasi belajar peserta didik yang tinggi. Sedangkan faktor penghambat: (1) guru masih kesulitan dalam proses penilaian siswa; (2) sikap siswa yang terlalu aktif; (3) karakteristik peserta didik yang berbeda-beda.

\section{SIMPULAN}

Perbandingan penerapan model Discovery Learning dalam pembelajaran IPA di MIN 1 Bantul dan SDIT BAIK Bantul, secara keseluruhan dari model pembelajaran Discovery Learning yang dilakukan di kedua kelas sudah melaksanakan semua tahapan proses pembelajaran dengan menggunakan model Discovery Learning dengan baik, hanya saja terkadang urutannya tidak urut, tetapi secara umum sudah disebut baik. implementasi model Discovery Learning dalam pembelajran IPA di kelas V MIN 1 Bantul dan SDIT BAIK Bantul, menunjukkan bahwa secara keseluruhan guru sudah melaksanakan langkah-langkah pembelajaran model Discovery Learning (a) stimulasi, guru menstimulus peserta didik dengan memberikan sebuah gambar, (b) problem statement, guru memberikan gambar lalu peserta didik mengidentifikasi masalah yang terdapat dalam gambar terebut, (c) data collection, peserta didik diberikan pengalaman mencari alternatif pemecahan masalah, (d) data processing, melatih peserta didik mencoba dan mengeksplorasi kemampuannya. Dan yang terakhir (e) verification dan generalitation, peserta didik berdiskusi dan mengkomunikasikan hasil diskusinya di depan kelas. Sedangkan faktor pendukung dan pengahambat; Faktor pendukung (1) ketelatenan guru, (2) pengemasan pembelajaran yang menarik, (3) tersedia media pembelajaran yang memadahi, (4) terjalinnya komunikasi yang baik., (5) motivasi belajar peserta didik yang tinggi. Sedangkan Faktor penghambat, (1) proses penilaian siswa, (2) sikap peserta didik yang terlalu aktif, (3) karakteristik siswa yang berbedabeda.

\section{DAFTAR PUSTAKA}

Abidin, Y. 2014. Desains System Pembelajaran dalam Konteks Kurikulum 2013. Bandung: Refika Aditama

Angel Gurría OECD Secretary-General, Snapshot of students' science beliefs, engagement and motivation. dalam http://www.oecd.org/pisa/pisa-2015results-in-focus.pdf di akses 15-12-2017.

Azwar, S. 1999. Metode Penelitian. Yogyakarta: Pustaka Pelajar.

Hamid, S. H., dkk. 2010. Pengembangan Pendidikan Budaya dan Karakter Bangsa Pedoman Sekolah. Jakarta: KementrianPendidikan Nasional, Badan Penelitian dan Pengembangan Pusat Kurikulum. 


\section{Emha \& Andi, Implementasi Model Discovery Learning...}

Howe, A. C. \& Jones, L. 1993. Engaging Childern in science. New York: Macmilan Publishing Company.

Ghoni, D. \& Almansur, F. 2012. Metode Penelitian Kualitatif. Yogyakarta: Ar-Ruzz Media

Jumali, M., Surtikanti, \& Sundari. 2008. Landasan Pendidikan Surakarta: UMS.

Kemdikbud,http://nasional.kompas.com/read/2016/12/15/23091361/daya.imajinasi.sisw a.lemah. di akses 15-12-2017

Kepala Puspendik dalam Seminar bertajuk "Hasil Penilaian Pendidikan untukKebijakan"yangdilaksanakanPusatPenilaianPendidikan,BadanPenelitiand anPengembangan,Kemdikbud,http://nasional.kompas.com/read/2016/12/15/23 091361/daya.imajinasi.siswa.lemah. di akses 15-12-2017.

Majid, A. \& Rochman, C. 2015. Pendekatan Ilmiah Dalam Implementasi Kurikulum 2013. Bandung: PT Remaja Rosdakarya

Mardalis. 2008. Metode Penelitian "Suatu Pendekatan Proposal”. Jakarta: Bumi Aksara.

Moleong, L. J. 2007. Metode Penelitian Kualitatif. Bandung: Remaja Rosdakarya.

Mulongo, G. 2013. Effect of Active Learning Teaching Methodology on Learner Participation. Journal of Education and Practice. Vol. 4, No. 4.

Prastowo, A. 2014. Pembelajaran Kontruktivistik;Scientific untuk Pendidikan Agama di Sekolah/Madrasah; terkait teori, aplikasi dan riset. Jakarta: Rajawali Press

Prastowo, A. 2014. Pengembangan Bahan Ajar Tematik Tinjauan Teoritis dan Praktik, Jakarta: Kencana Predanamedia Group 2014.

Sa'ud, U. 2011. Inovasi Pendidikan. Bandung: ALFABETA

Samatowa, U. Pembelajaran IPA di Sekolah Dasar. Jakarta : PT Indeks.

Sugiyono. 2010. Metode Penelitian Pendidikan Pendekatan Kuantitatif, Kualitatif, dan $R \& D$. Bandung: Alfabeta.

Sukmadinata, N. S. 2010. Metode Penelitian Pendidikan. Bandung: PT Remaja Rosdakarya.

Suprihatiningrum, J. 2016. Strategi Pembelajaran; teori \& aplikasi. Yogyakarta: ArRuzz Media.

Syah, M. 2010. Psikologi Pendidikan. Bandung: Remaja Rosdakarya.

Toharudin, dkk. 2011. Membangun Literasi Sains Peserta Didik. Bandung: Humaniora. 